\title{
Recent developments in the study of Early Bronze Age Crete (Early Minoan Period)
}

Borja Legarra Herrero (UCL)

b.legarra@ucl.ac.uk

\begin{abstract}
The production and publication of new research on the Cretan Early Bronze has accelerated tremendously in the last decades. This article aims to present the highlights and main trends in the last 15 years: the sites, the excavations, the research projects and the main publications. Moreover, it explores how the new data interlinks with the extremely large body of information available from more than 100 years of archaeological studies on Crete. The aim of such a review is to eventually identify the larger patterns of research, the popular themes, the strengths and weaknesses of the data recovered, and to consider the place of Early Bronze Crete in current trends in Mediterranean Prehistory and archaeology as a whole.
\end{abstract}

\section{Introduction}

This article presents an extensive, but not exhaustive, review of new data and research on the Cretan Early Bronze Age (EBA) published until summer 2019 including reports from the Archaiologikon Deltion, the Praktika tes en Athenais Archaiologikes Hetaireias, Archaeology in Greece Online, Ergo Kretes and the ongoing publication of the 12th International Congress of Cretan Studies as well as other publications.

There are three particularities that the reader should be aware of first. The first is the continuing preponderance of mortuary sites in the study of EBA Crete, largely explained by biases in archaeological preservation as most cemeteries are not buried underneath later remains as is the case for EBA settlements. Excavation procedures have become more demanding and time consuming, leading to less time to dig deeper into the Prepalatial levels. The funerary context of most of the data presents a strong and particular bias in the study of EBA Crete. Second, the article avoids the term 'Early Minoan' to refer to the period and uses instead the term 'EBA Crete', although ceramic dating conventions are kept for clarity (e.g. Early Minoan [EM] I, IIA, IIB and III) (Fig. 1). There are several reasons for this decision: the term is laden with meanings acquired over 100 years of research that create the illusion of a distinct and homogeneous culture across the island which may mask our understanding of important variations in the archaeological record (Legarra Herrero 2009). Moreover, it implies a chronological distinction from neighbouring regions, one that we have not clearly established, while at the same time isolating the archaeology of this island academically, creating the impression that it is a world very different to other regions, set apart by a distinct and independent history.

Finally, there is a third particularity that has to do with chronology. Recent research has questioned whether the traditional separation between the Final Neolithic and Early Bronze makes any sense (Tomkins 2004). Many major changes that had already started at the end of the Neolithic continued into the EBA which renders the traditional terminology and the attached academic fault lines misleading. The chronological divisions are also problematic to understand the end of the EBA and the start of the Protopalatial period (Schoep 2012). The 
awkward distinction between EM III, MM IA (Prepalatial) and MM IB (Protopalatial) of what otherwise seems like a common period of change is the best example of this problematic approach. On the other hand, it is impossible, given the wealth of data, that this review can do any justice to the Neolithic and Middle Bronze Age. It will, therefore, mainly focus on the EBA, establishing the connections with earlier and later periods when pertinent.

\section{New excavations and new information from old excavations (Map 1)}

\section{Funerary}

Two major cemeteries have dominated the studies along the north coast of Crete in the last ten years or so, namely Sissi (Crevecoeur et al. 2015; Schoep 2009; Schoep et al. 2011; Schoep et al. 2013) (Fig. 2) and Petras (Tsipopoulou 2010; 2012c; 2017b) (Fig. 3). They are remarkable not just because of their size and preservation but also because of the high standards of excavation, informative project websites and the quick publication of preliminary reports. ${ }^{1}$

At Sissi, evidence of Prepalatial habitation has been found at the site (EM II and EM III/MMIA; Devolder 2012) (ID 260, ID775, ID1800, ID1912, ID5574, ID6048). At Petras, a small FN/EM I hamlet has been excavated and reported from nearby the cemetery (Papadatos 2012a; 2012b) (ID 1793, ID5521) and there is evidence for EM II habitation underneath the nearby Proto- and Neopalatial settlement (Tsipopoulou 1999). The two cemeteries are composed by several square tombs. Those at Sissi seem to have first been built in EM I/IIA and at Petras in EM IIA (Tsipopoulou 2017b: 72-3), although the main use of the two cemeteries dates from the late Prepalatial to the Protopalatial (Schoep et al. 2013; Tsipopoulou 2017b). Tombs in both sites included a rich assemblage of items (e.g. Ferrence et al. 2012; Giumlia-Mair et al. 2017; Krzyszkowska 2012) and architectural features (Betancourt 2012a) and were surrounded by open spaces in which rituals may have taken place (Tsipopoulou 2017a). The most valuable information comes from the detailed excavation and study of the burial deposits at the two sites which are already providing much needed information about number and sequence of interments, and the manipulation of human remains (Crevecoeur et al. 2015; Schoep et al. 2017; Triantaphyllou 2017; Triantaphyllou et al. 2017).

The recent publication of the cemeteries of Pseira and Hagia Photia in the north coast has provided more limited information due to their poor preservation. At Pseira (Betancourt and Davaras 2002; 2003) (ID 1796), 19 small tombs were reported ranging from cists to square built ones. They generally contained little material (Betancourt 2011). The Hagia Photia cemetery is more remarkable: it includes hundreds of chamber and cist tombs typical of the Cyclades and contains mainly Cycladic-style pottery (Davaras and Betancourt 2004; 2012) made locally on Crete (Day et al. 1998). The cemetery is at the centre of discussions about the relationship between the Cyclades and Crete during the EM I and early EM II period (see below). The, as yet unpublished, cemetery at Gournes (Galanaki 2006; Galanaki

${ }^{1}$ https://sarpedon.be/ (Sissi) and https://www.petras-excavations.gr/ (Petras). 
et al. 2011) (ID 194, ID 2830)shares many traits with Hagia Photia and will provide new data about the phenomenon of Cycladic-style cemeteries on Crete. Finally, new excavations have been conducted at Mochlos (ID 1909), with several new tombs discovered (Soles 2012: 197) in the previously excavated cemetery. There are also reports of FN-EM I burials underneath Late Bronze Age remains in Kephali Sphendyli (Bennet 2012) (ID 2786) (FIG. 4)near Chersonissos.

The study of tholos tombs has not slowed down either, spearheaded by publication of the cemeteries at Moni Odigitria (Vasilakis and Branigan 2010), Tholos Gamma at Archanes Phourni (Papadatos 2005), Livari (Papadatos and Sofianou 2015) (ID 762, ID 763, ID 1785, ID 2809, ID 3576) and the ongoing study of the Koumasa cemetery (Boness and Goren 2017; Panagiotopoulos 2012; 2013; 2014; 2015; 2016) (ID 3409, ID 4436, ID 5438, ID 5439, ID 6538, ID 6539, ID 6808) (Figs. 5 and 6). The Livari tholos together with that excavated at Messorachi (ID 2802) near Sitia is challenging our association of tholos tombs with south central Crete (Papadatos and Sofianou 2012), particularly as their construction in EM I is roughly contemporaneous with that of many of the Mesara tombs (Legarra Herrero 2014a). The research in tholos tombs is also being advanced through the re-study of previous excavations. This is the case of the aforementioned Koumasa cemetery, Apesokari A (Flouda 2013), Apesokari B (Vavouranakis 2012; Vavouranakis and Bourbou 2015), Hagia Triada A (Cultraro 2004; Todaro 2004), Kamilari (Girella 2012; 2013; 2018) and Krasi (Galli 2014). Researchers have shown that fresh information can be extracted from the re-study of the material from the old excavations kept in the Cretan museums.

One of the main contributions of the new publications is the fresh information on human remains. The publication of Tholos Gamma at Archanes Phourni was one of the first to include a study of human remains (Triantaphyllou 2005) and opened the way for what it has now become standard practice in the publication of tholos tombs (Triantaphyllou 2009; 2010; Vavouranakis and Bourbou 2015). Micro-stratigraphic data from the new excavations at the Koumasa tholos tombs presents complementary information to understand the history of use and episodes of clearing in the communal tombs (Boness and Goren 2017). One can only hope that more of such type of analysis will be conducted in the future. It is also worth mentioning recent work in the analysis of tholos tomb location, particularly in how they structure movement and facilitate interaction across communities in south central Crete (Déderix 2016; Déderix and Sarris 2019; Paliou and Bevan 2016).

Beyond the data from the north coast and tholos tombs, little new information is coming from other regions which is mainly explained by the regional bias of our research history. Recent publication of the two rectangular tombs in the outskirts of Zakros (Platon 2017; Platon and Tsiboukaki 2017) (ID 171, ID 252, ID 756, ID 1806, ID 1874, ID 209) serves as a strong reminder of the remarkable EBA funerary record in other parts of the island.

Non-Funerary 
New non-burial EBA sites are rare and most of the evidence comes from settlements best known in later periods. There are exceptions such as the small EM I sites at Kephali Afroditi (Betancourt 2013) (ID 764), a peculiar small walled site that does not seem to have a domestic use (Fig. 7), and the FN-EM I settlement at Petras Kephala (Papadatos 2008; 2012a; 2012b) near the Prepalatial cemetery. The rock shelter at Alatzomouri is one of the few closed EM III deposits known on Crete and it is proving crucial for the better understanding of the period's ceramic sequence, although the nature of the site is difficult to define (Apostolakou et al. 2017). More material has come from multiperiod excavations such as those at Pryniatikos Pyrgos (Molloy et al. 2014; Pavlacky 2019) (ID 773, ID 2003), Gournia (Watrous et al. 2015) (ID 1910, ID 2860, ID 4551), Chania (Evely 2010: 195) (ID 1851, ID 2834, ID 2838, ID 3585, ID 4520) (Fig. 8) and Sissi (Devolder 2012).

Work in EBA Knossos has continued with the publication of several EBA deposits underneath and around the palace (Wilson 2010; Hood and Cadogan 2011) and the revision of the ceramic sequence (Momigliano 2007; Wilson 2007). The new data is informing the debate about the EM development of the site (more below). The evidence for EM I-II use of the nearby harbour of Poros has been reported only preliminarily. These reports contain useful information about production and off-island exchange (Dimopoulou-Rethemiotaki et al. 2007; Doonan et al. 2007; Wilson et al. 2008) (ID 3651).

At Phaistos and Hagia Triada, new and old data are being combined in a comprehensive restudy of these sites, including their EBA use (Todaro 2005; 2009; 2010; 2012). Shaw's revision of the early architectural features of certain Cretan sites, particularly Vasiliki, is also providing precious new information from old excavations (Shaw 2016; 2017).

The popularity of intensive survey on Crete has not decreased in the last few years (Fig. 9). Surveys in the areas of Vrokastro (Hayden 2003; 2004; 2005), Gournia (Watrous 2012) (ID 766, ID 1783) and Kavousi (Haggis 2005) in the Mirabello area have provided us with a comprehensive understanding of the region to complement the excavations conducted in the area (e.g. Pryniatikos Pyrgos, Alotzomouri, Pseira, Gournia). The Knossos Urban Landscape Project is also providing new information about the size and development of the EBA settlement at this key site (Legarra Herrero 2019) (Fig. 10) (ID 199, ID 263, ID 783, ID 1811, ID 1920, ID 2815, ID 2900) . In central Crete, the survey of the region of Galatas has been recently published (Watrous et al. 2017). In south central Crete, the west Mesara survey (Watrous et al. 2004) has been complemented by smaller, but more focused, surveys on the EBA period at Moni Odigitria (Vasilakis and Branigan 2010) (Fig. 11) and the Trypiti area (Vasilakis and Sbonias 2018) (Fig. 12). These surveys are providing a much-needed update on the relationship between tholos tombs and human settlement to add to the existing information about burial groups as we now know them thanks to the recent studies on human remains.

\section{Publications}


The number of publications regarding EBA Crete in the last 15 years means that there are too many to include in this review. Some works, however, are worth mentioning for their impact on the field and also for opening new trends in the study of the period.

Monographs focused on the study of EBA Crete are rare. Since the work of Branigan (Branigan 1988) and Watrous (Watrous 1994; 2001) no overall overview of the period has been provided although a couple of good introductions have appeared in the form of book chapters (Manning 2008; Wilson 2008). The recent publication of a comprehensive monograph on the study of Early and Middle Bronze Age tombs reviews much of the data for the Prepalatial and presents a detailed catalogue of known burial sites (Legarra Herrero 2014a). Otherwise, monographs on the period are scarce and normally more limited in scope, such as Anderson's (2016) study of the MM I 'Parading Lion' seals.

The most influential publications have come in the shape of edited volumes. In 2004, a book to commemorate Renfrew's (1972) Emergence of Civilisation included several articles that have since become extremely influential (Bevan 2004; Cherry 2004; Renfrew 2004; Schoep and Knappett 2004; Tomkins 2004; Whitelaw 2004a). Eight years later, a book edited by Schoep, Driessen and Tomkins had a similar impact and included a whole new range of approaches to conceptualise the period (Driessen 2012b; Legarra Herrero 2012; Relaki 2012; Schoep 2012; Schoep and Tomkins 2012; Todaro 2012; Tomkins 2012; Whitelaw 2012b).

Last year, the publication of a festschrift in honour of Professor Keith Branigan included several papers that present theoretical approaches to the EBA (Driessen 2018; Schoep 2018; Tomkins 2018; Whitelaw 2018). Some of this work is part of the continued theoretical interest in urbanism and political economy (Bevan 2010; Whitelaw 2012b; 2017), but there are also indications of new research trends (e.g. Hamilakis 2018). The recent volume publishing the research of several young academics on the Aegean also provides a good insight into new themes and approaches (Karacic 2015; Déderix 2016; Mina 2016; Soar 2016). In particular ideas of embodiment, performance and ritual practice are becoming increasingly popular (Todaro 2012; Hamilakis 2014; Soar 2014; Legarra Herrero 2016a; Tomkins 2018).

\section{Academia and the nature of research}

We have already mentioned the ongoing trend of revisiting old excavations in order to learn new information. As research excavations become more expensive with added logistical complexities, surveys and smaller projects revisiting the wealth of material in museums are becoming more common. Recent exceptions are the excavations at Prinitatikos Pyrgos (Hayden et al. 2007; Molloy et al. 2014), Petras (Tsipopoulou 2012a; 2017b) and Sissi (Driessen 2009; 2012a; Driessen et al. 2009) which all had explicit EBA interests in their design. Unfortunately, there seems to be few new projects of this kind on the horizon and most new material is coming from rescue excavations such as Kephali Sphendyli (Bennet 2012) or Livari (Papadatos and Sofianou 2015) that have limitations in terms of resources and design. Such changes in data acquisition could have a deep impact on the way EBA studies will shape in the next decades. 
In terms of analytical approaches, the last few years of the Cretan EBA have been a mixed bag. There have been major developments, particularly in the excavation and study of human remains (see above and reviews in Girella and Todaro 2016; Legarra Herrero 2018a; Triantaphyllou 2018). Work on ceramic assemblages at Knossos (Momigliano 2007; Wilson 2007; 2008; 2010) and Phaistos (Todaro 2009; 2010; 2012), but also other areas in the east (Apostolakou et al. 2017; Betancourt 2010; 2012b; Betancourt 2013; Davaras and Betancourt 2012; Day 2014; Tsipopoulou 2012b) has also been quite dynamic, moving away from typological approaches towards more technological studies that explicitly investigate the relationship between production, consumption choices and social practices.

To a lesser extent, such interest in technology has been also applied to other materials such as obsidian (Carter 2003; D'Annibale 2008; Dierckx 2012), stone vessels (Bevan 2007; Morero and Prévalet 2015; Relaki and Tsoraki 2017) and goldwork (Colburn 2011; Hickman 2011; 2012; Legarra Herrero 2014b; 2018b). Progress is, however, patchy and there are many areas that have seen limited development. A promising set of studies in bronze and silver metallurgy during the 2000s (Betancourt and Muhly 2007; Catapotis et al. 2011; Clinton et al. 2009; Dimopoulou 2012; Galanaki et al. 2011; Muhly 2008; Papadatos 2007; Tselios 2008) led by the publication of the metallurgical workshop at Chrysokamino (Betancourt 2006; 2007; 2008; Catapotis and Bassiakos 2007; Catapotis et al. 2008) seems to have slowed down. There have been few new scientific studies recently. Studies of stone tools, archaeobotany, and archaeozoology (Livarda and Kotzamani 2014) are rare even in excavation reports (Isaakidou 2017a; 2017b; Isaakidou et al. 2011; Margaritis 2017; Molloy et al. 2014; Tsoraki 2012; Veropoulidou 2012; Watrous et al. 2015) and virtually unknown from funerary contexts.

Isotopic analysis and DNA are rapidly becoming central in the discipline of archaeology but they have a very limited development in EBA Crete. Isotopic analysis of EBA tombs have only started to appear in the literature (Triantaphyllou et al. 2015) despite their potential to answer many questions about the make-up of the tombs, origin of those interred and differences in diet - all major questions in the study of the Cretan burial record. DNA has been sampled from a couple of EBA contexts but these have been published as part of a kind of chronologically-vague and low-resolution analysis (Lazaridis et al. 2017) that has received much criticism lately (e.g. Booth 2019; see also Vander Linden 2016). The rich EBA burial record would provide a useful basis for highly innovative DNA and isotopic analysis about relations between the deceased and comparisons of the demographic composition between tombs and cemeteries. At the moment, the potential of such approaches is unfulfilled and barely on the academic radar of EBA Crete (Triantaphyllou et al. 2015).

A particularly crippling problem is the lack of an absolute chronology for the period under consideration (Manning 2017; 2018). Despite major developments in Bayesian approaches to chronology and their successful application to communal burials elsewhere, there is a distinct lack of radiocarbon or other types of scientific dating on the island. Manning's recent article is only able to model a few radiocarbon samples taken more than 40 years ago. This uncertainty presents major problems in understanding periods such as the EM IIB / EM III gap (Brogan 2013) and its link with the major 2200 BC climatic event; or to determine 
the lengths of key periods such as the MM IA and MM IB (Manning 2017). These can fluctuate in the literature between 75 and 150 years, which has a major impact on the way in which we characterise the major cultural changes that happened on the island at this point. The recent revision of the Near Eastern chronology at the beginning of the $2^{\text {nd }}$ millennium BC (Höflmayer 2017; 2018; Manning 2017) has important repercussions for the study of the first links between the east Mediterranean and Crete. This development makes the need for chronological analyses more evident.

The study of EBA Crete is noticeably behind in several key scientific areas which presents obstacles in the connection of the archaeology of the island with wider academia. The impact can already be felt as Crete, despite its crucial place in the understanding of European prehistory, is being excluded from innovative large-scale projects. ${ }^{2}$ This not only has major consequences in terms of lost funding opportunities but more importantly it diminishes the general relevance of Cretan archaeology, making it less attractive to academics and students.

More encouraging is the recent work on the study of early script on Crete, which although it only touches the end of the EBA, is providing much needed new insights in how script might have developed on the island early in the 2nd millennium BC (Decorte 2018a; 2018b; see also Ferrara and Jasink 2017; Militello 2017). Such new impetus clearly has synergies with the strong research body of sphragistic and glyptic research on Pre- and Protopalatial Crete (Anastasiadou 2016; Anderson 2016; Krzyszkowska 2012; 2017; Panagiotopoulos 2014; 2015; 2016; Relaki 2010; Sbonias 2010; 2012). One of the main strengths of this new research is that it is explicitly comparative with the invention of script in other parts of the world.

\section{Major themes and discussions}

The varied and rich record of the EBA provides much food for thought in a variety of fields, but there are two fields in particular that tend to dominate the literature: processes of socio-political complexity and cultural interaction.

Since the publication of The Emergence of Civilisation (Renfrew 1972), the appearance of complex societies on Crete has been central to understanding the EBA period. The 3rd millennium BC was understood as a gradual climb towards state organisation (Branigan 1988). The 2004 edited volume is a reminder of how influential the 1972 publication has been and the ongoing struggle with the neo-evolutionary paradigm that it established (Barrett and Damilati 2004; Cherry 2004; Schoep and Knappett 2004; Whitelaw 2004a).

The debate about whether state formation was a process that already started early in the EBA or whether it is better understood as a rapid revolution that occurred at the end of the 2nd millennium $B C$ has itself evolved but not disappeared. Recent work proposes early beginnings for socio-political processes leading to state formation, long before the

\footnotetext{
${ }^{2}$ E.g. see the conspicuous absence of Crete from Weiberg et al. 2019.
} 
Protopalatial period. A number of authors have identified Knossos and Phaistos as special ceremonial sites from an early date, with a central role already in the Neolithic that would only keep developing over the EBA (Day and Wilson 2002; Driessen 2007; Schoep 2012; Todaro 2009; 2012; Tomkins 2012). Another group of authors find the evidence for the early stages on Knossos and Phaistos comparable with what we know from other EBA settlements on the island (Cherry 2010; Legarra Herrero 2014a; Whitelaw 2012b; 2017). These authors emphasise the major and rapid changes in settlement size at these sites at the end of the 2nd Millennium BC coinciding with a new wave of connections between Crete and the east Mediterranean.

To add further complexity to these debates, almost every component of the discussion has been under recent scrutiny. First, regional differences are starting to be acknowledged and the possibility of several histories for the island opens new areas of research in regionalism and the links between different scales of human experience (Legarra Herrero 2009; Pavlacky 2019; Relaki 2004; 2012). The EBA is no longer seen in terms of steady development, but as a non-linear and slightly chaotic period that includes crises, collapses and even relatively static periods (Legarra Herrero 2012; Whitelaw 2004a; 2012b). The role of elites, traditionally evoked as crucial for change, is being re-examined and new ideas of change based on collective action (Hamilakis 2002; Legarra Herrero 2016b; Schoep 2006; Schoep and Tomkins 2012; Vavouranakis 2017) and group identities (Driessen 2012b; 2016; 2018) are being put forward.

The study of inter-cultural contact between Crete and the rest of the Mediterranean is undergoing similar critical inspection. Much of the debate for the FN to EM IIA periods revolves around the relationship between Crete and the Aegean, based on an increasingly sophisticated understanding of cultural contacts, population movement and exchange of material culture (Betancourt 2009; Betancourt et al. 2016; Brogan 2013; Catapoti 2011; Doumas 2010; Karantzali 2008; Papadatos 2008; 2012a; Papadatos and Tomkins 2013; Stampolidis and Sotirakopoulou 2017). Ideas of Cycladic migrants are being substituted with more nuanced scenarios that include a range of cultural interactions, such as acculturation, immigration, adoption, resistance. It is increasingly clear that Crete did not just receive but also modified and adapted Aegean items to its own tastes (see e.g. Stampolidis and Sotirakopoulou 2017).

After the EM IIB period something changes and by the end of the EM III period the off-island connections moved to the east Mediterranean as Near Eastern and Egyptian items start appearing on Crete. Some authors see this shift as the proof of direct influence from the powerful states in the east Mediterranean (Warren 2005; Watrous 2005; Wiener 2013), but analysis of the material, production and consumption contexts provides a different picture (Bevan 2007; Cherry 2010; Galaty et al. 2010; Legarra Herrero 2011; Morero and Prévalet 2015; Phillips 2006; 2008). Crete seems to make decisions about how to engage with the wider world and deploys a range of strategies in what seems to be a multi-layered and flexible approach to adapting off-island influences to local social and cultural structures. In this respect, Cretan state formation may be better understood through the internal decisions made by Cretan communities (Legarra Herrero 2016c). 


\section{EBA Crete and the modern archaeological context}

The themes described above connect with major debates in archaeology and with big questions about the human past. In the last few years, authors have tried to link Cretan state formation (Legarra Herrero 2016c; Parkinson and Galaty 2007) and early urbanism (Whitelaw 2012a; 2017) with wider debates in these topics through publications in international forums. As more importance is given to the large-scale in order to explain the past, more comparisons between Crete, the Aegean and the Mediterranean are starting to appear (Broodbank 2013; Legarra Herrero 2016b; Manning 2018; Weiberg 2017; Whitelaw 2017). These efforts are crucial for the future of the discipline. Archaeological research focussing on smaller regional questions and debates is becoming more difficult to fund and more support is given to larger projects that tackle big questions. EBA Crete needs to come out of its shell and establish its key importance in any such analysis.

\section{Conclusions}

The wealth of high-quality data gathered over the last 15 years, along with the comprehensive datasets that have been built for more than a century, bodes well for an exciting future. The challenge will be to convert this critical mass of information into methodologically and theoretically innovative studies that explicitly explore high-impact questions about mobility, cultural interaction and socio-economic organisation. The next 15 years will see not only new approaches being developed on Crete but also more Cretan data and analyses featuring prominently in wider archaeological discussions.

\section{Bibliography}

Anastasiadou, M. (2016) 'Drawing the Line: Seals, Script, and Regionalism in Protopalatial Crete', AJA 120, 159-93

Anderson, E.S.K. (2016) Seals, Craft, and Community in Bronze Age Crete (Cambridge)

Apostolakou, V., Brogan, T.M. and Betancourt, P.P. (2017) The Alatzomouri rock shelter: an early Minoan III deposit in eastern Crete (Philadelphia)

Barrett, J.C. and Damilati, K. (2004) "Some Light on the Early Origins of Them All':

Generalization and the Explanation of Civilization Revisited', in Barrett, J.C. and Halstead, P. (eds), The Emergence of Civilisation Revisited (Oxford) 145-69

Bennet, J. (2012) 'Crete (Prehistoric to Roman). Archaeology in Greece 2011-2012', AR 58, 58-74

Betancourt, P.P. (2006) The Chrysokamino metallurgy workshop and its territory (Princeton) 
Betancourt, P.P. (2007) 'The Final Neolithic to Early Minoan III Metallurgy Site at Chrysokamino, Crete', in Day, P.M. and Doonan, R.C.P. (eds), Metallurgy in the Early Bronze Age Aegean (Oxford) 57-67

Betancourt, P.P. (2008) 'The Copper Smelting Workshop at Chrysokamino: Reconstructing the Smelting Process', in Tzachili, I. (ed.), Aegean Metallurgy in the Bronze Age. Proceedings of an International Symposium held at the University of Crete, Rethymnon, Greece, on November 19-21, 2004 (Athens) 105-112

Betancourt, P.P. (2009) The Bronze Age Begins: The Ceramics Revolution of Early Minoan I and the New Forms of Wealth That Transformed Prehistoric Society (Philadelphia)

Betancourt, P.P. (2010) 'The EM I pithoi from Aphrodite's Kephali', in Krzyszkowska, O. (ed.), Cretan Offerings. Studies in Honour of Peter Warren (Athens) 1-10

Betancourt, P.P. (2011) 'Tomb 4 at Pseira: Evidence for Minoan Social Practices', in Murphy, J.M.A. (ed.), Prehistoric Crete: Regional and Diachronic Studies on Mortuary Systems (Philadelphia) 85-103

Betancourt, P.P. (2012a) 'The architecture of the house tombs at Petras', in Tsipopoulou, M. (ed.), Petras, Siteia - 25 years of excavations and studies. Acts of a two-day conference held at the Danish Institute at Athens, 9-10 October 2010 (Athens) 107-17

Betancourt, P.P. (2012b) 'The frying pans from Hagia Photia', in Matzourani, E. and Betancourt, P.P. (eds), Phillistor. Studies in Honor of Costis Davaras (Philadelphia) 1-6

Betancourt, P.P. (2013) Aphrodite's Kephali: an early Minoan I defensive site in Eastern Crete (Philadelphia)

Betancourt, P.P. and Davaras, C. (2002) Pseira VI. The Pseira Cemetery 1. The Surface Survey (Philadelphia)

Betancourt, P.P. and Davaras, C. (2003) Pseira VII. The Pseira Cemetery 2. Excavation of the Tombs (Philadelphia)

Betancourt, P.P., Ferrence, S.C. and Muhly, J.D. (2016) 'Cycladic and More Northerly Connections in the Metal Objects from Petras Cemetery. A New York Aegean Bronze Age Colloquium in Memory of Ellen N. Davis', in Koehl, R.B. (ed.), Studies in Aegean Art and Culture (Philadelphia) 35-46

Betancourt, P.P. and Muhly, J.D. (2007) 'The Crucibles from the Aghia Photia Cemetery', in Day, P.M. and Doonan, R.C.P. (eds), Metallurgy in the Early Bronze Age Aegean (Oxford) 146-53

Bevan, A. (2004) 'Emerging Civilized Values? The Consumption and Imitation of Egyptian Stone Vessels in EMII-MMI Crete and its Wider Eastern Mediterranean Context', in Barrett, J.C. and Halstead, P. (eds), The Emergence of Civilisation Revisited (Oxford) 107-26

Bevan, A. (2007) Stone Vessels and Values in the Bronze Age Eastern Mediterranean (Cambridge) 
Bevan, A. (2010) 'Political Geography and Palatial Crete', JMA 23, 27-54

Boness, D. and Goren, Y. (2017) 'Early Minoan mortuary practices as evident by microarchaeological studies at Koumasa, Crete, applying new sampling procedures', Journal of Archaeological Science: Reports 11, 507-22

Booth, T.J. (2019) 'A stranger in a strange land: a perspective on archaeological responses to the palaeogenetic revolution from an archaeologist working amongst palaeogeneticists', WorldArch, 1-16

Branigan, K. (1988) Pre-Palatial. The Foundations of Palatial Crete. A Survey of Crete in the Early Bronze Age (Amsterdam)

Brogan, T.M. (2013) '"Minding the Gap": Reexamining the Early Cycladic III "Gap" from the Perspective of Crete. A Regional Approach to Relative Chronology, Networks, and Complexity in the Late Prepalatial Period', AJA 117, 555-56

Broodbank, C. (2013) The Making of the Middle Sea. A history of the Mediterranean from the Beginning to the Emergence of the Classical world (London)

Carter, T. (2003) 'Problematizing the Analysis of Obsidian in the Aegean and Surrounding Worlds', in Foster, K.P. and Laffineur, R. (eds), METRON. Measuring the Aegean Bronze Age. Proceedings of the 9th International Aegean Conference / 9e Rencontre égéenne internationale. New Haven, Yale University, 18-21 April (2002), Aegaeum 24 (Liège) 75-82

Catapoti, D. (2011) 'Further thoughts on the International Spirit: maritime politics and consuming bodies in the early Cyclades', in Vavouranakis, G. (ed.) The seascape in Aegean Prehistory (Athens) 71-90

Catapotis, M. and Bassiakos, Y. (2007) 'Copper Smelting at the Early Minoan site of Chrysokamino on Crete', in Day, P.M. and Doonan, R.C.P. (eds), Metallurgy in the Early Bronze Age Aegean (Oxford) 68-83

Catapotis, M., Bassiakos, Y. and Papadatos, Y. (2011) 'Reconstructing Early Cretan Metallurgy: Analytical Evidence from Kephala Petras, Siteia', in Betancourt, P.P. and Ferrence, S.C. (eds), Metallurgy: understanding how, learning why. Studies in Honor of James D. Muhly (Philadelphia) 69-78

Catapotis, M., Pryce, O. and Bassiakos, Y. (2008) 'Preliminary Results from an Experimental Study of Perforated Copper-smelting Shaft Furnaces from Chrysokamino (easter Crete)', in Tzachili, I. (ed.), Aegean Metallurgy in the Bronze Age. Proceedings of an International Symposium hel at the University of Crete, Rethymnon, Greece, on November 19-21, 2004 (Athens) 113-22

Cherry, J.F. (2004) 'Chapter 14 Revisited: Sites, Settlement and Population in Prehistoric Aegean Since The Emergence of Civilisation ', in Barrett, J.C. and Halstead, P. (eds), The Emergence of Civilisation Revisited (Oxford) 1-20 
Cherry, J.F. (2010) 'Sorting Out Crete's Prepalatial Off-Island Interactions', in Parkinson, W.A. and Galaty, M.L. (eds), Archaic State Interaction. The Eastern Mediterranean in the Bronze Age (Santa Fe) 107-40

Clinton, M.G., Martino, S., Myer, G.H., Terry, D.O.J. and Betancourt, P.P. (2009) 'Rapid Cooling Effects in Early Bronze Age Copper Smelting Slags from Chrysokamino', Aegean Archaeology 8, 21-30

Colburn, C.S. (2011) 'Egyptian Gold in Prepalatial Crete? A Consideration of the Evidence'. Journal of Ancient Egyptian Interconnections 3, 1-13

Crevecoeur, I., Schmitt, A. and Schoep, I. (2015) 'An archaeothanatological approach to the study of Minoan funerary practices: Case-studies from the Early and Middle Minoan cemetery at Sissi, Crete', Journal of Field Archaeology 40, 283-99

Cultraro, M. (2004) 'La grande tholos di Haghia Triada: nuovi dati per un vecchio complesso', Creta Antica 4, 301-28

D'Annibale, C. (2008) 'Obsidian in Transition: the Technological Reorganization of the Obsidian Industry from Petras Kephala (Siteia) between Final Neolithic IV and Early Minoan I', in Isaakidou, V. and Tomkins, P.D. (eds), Escaping the Labyrinth. The Cretan Neolithic in Context (Oxford) 191-201

Davaras, C. and Betancourt, P.P. (2004) The Hagia Photia Cemetery I. The Tomb Groups and Architecture (Philadelphia)

Davaras, C. and Betancourt, P.P. (2012) The Hagia Photia Cemetery II. The Pottery (Philadelphia)

Day, J. (2014). 'Striped, Wiped and Granodiorite: Ceramics from the Early Mnoan I House at Pryniatikos Pyrgos', in Molloy, B. P. C. and Duckworth, C. N. (eds.), A Cretan Landscape through Time: Priniatikos Pyrgos and Environs. Oxford, Archaeopress: 125-134.

Day, P.M. and Wilson, D.E. (2002) 'Landscapes of Memory, Craft and Power in Prepalatial and Protopalatial Knossos', in Hamilakis, Y. (ed.) Labyrinth Revisited. Rethinking 'Minoan' Archaeology (London) 143-66

Day, P.M., Wilson, D.E. and Kiriatzi, E. (1998) 'Pots, labels and people: burying ethnicity in the cemetery at Aghia Photia', in Branigan, K. (ed.), Cemetery and Society in the Aegean Bronze Age (Sheffield) 133-49

Decorte, R.P.-J.E. (2018a) 'The First 'European' Writing: Redefining the Archanes Script', Oxford Journal of Archaeology 37, 341-72

Decorte, R.P.-J.E. (2018b) 'The Origins of Bronze Age Aegean Writing: Linear A, Cretan Hieroglyphic and a New proposed Pathway of Script Formation', in Ferrara, A. and Valério, M. (eds), Paths into Script Formation in the Ancient Mediterranean (Rome) PAGES NEEDED! 
Déderix, S. (2016) 'Capturing the Dynamics of Minoan Mortuary Space in South Central Crete', in Cappel, S., Günkel-Maschek, U. and Panagiotopoulos, D. (eds), Minoan Archaeology. Perspectives for the 21st century (Louvain-la-Neuve) 61-75

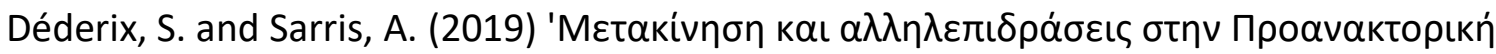

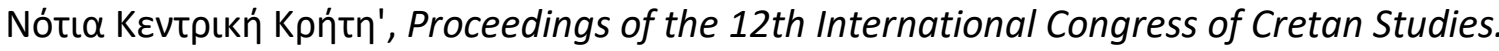
Herakleion 21-25.9.2016 (Herakleion) 1-17 [Online] Available: https://12iccs.proceedings.gr/en/proceedings/category/38/32/195

Devolder, M. (2012) 'The excavation of the open area north of Building E in Zone 5', in Driessen, J., Schoep, I., Anastasiadou, M., Carpentier, F., Crevecoeur, I., Déderix, S., Devolder, M., Gaignerot-Driessen, F., Jusseret, S., Langhor, C., Letesson, Q., Liard, F., Schmitt, A., Tsoraki, C. and Veropoulidou, R. (eds), Excavations at Sissi III. Preliminary Report on the 2011 Campaign (Louvain-la-Neuve) 117-34

Dierckx, H.M.C. (2012) 'Size does matter: the significance of obsidian microliths and querns at the Petras cemetery', in Tsipopoulou, M. (ed.), Petras, Siteia - 25 years of excavations and studies. Acts of a two-day conference held at the Danish Institute at Athens, 9-10 October 2010 (Atthens) 171-77

Dimopoulou-Rethemiotaki, N., Wilson, D.E. and Day, P.M. (2007) 'The Earlier Prepalatial Settlement of Poros-Katasambas: Craft Production and Exchange at the Harbour Town of Knossos', in Day, P.M. and Doonan, R.C.P. (eds), Metallurgy in the Early Bronze Age Aegean (Oxford) 84-97

Dimopoulou, N. (2012) 'Metallurgy and metalworking in the harbour town of Knossos at Poros-Katsambas', In Kassianidou, V. and Papasavas, G. (eds), Eastern Mediterranean Metallurgy and Metalwork in the Second Millennium BC. A conference in honour of James $D$. Muhly. Nicosia, 10th-11th October 2009 (Oxford) 135-41

Doonan, R.C.P., Day, P.M. and Dimopoulou-Rethemiotaki, N. (2007) 'Lame Excuses for Emerging Complexity in Early Bronze Age Crete: the Metallurgical Finds from Poros Katsambas and their Context', in Day, P.M. and Doonan, R.C.P. (eds), Metallurgy in the Early Bronze Age Aegean (Oxford) 98-122

Doumas, C. (2010) 'Crete and the Cyclades in the Early Bronze Age: a view from the north', in Krzyszkowska, O. (ed.) Cretan offerings. Studies in Honour of Peter Warren (Athens) 101-6

Driessen, J. (2007) 'Ilb or not Ilb: On the Beginnings of Minoan Monument Building', in Bretschneider, J., Driessen, J. and Van Lerberghe, K. (eds), Power and Architecture. Monumental Public Architecture in the Bronze Age Near East and Aegean. Proceedings of the international conference Power ad Architecture organized by the Katholieke Universiteit Leuven, the Université Catholique de Louvain and the Westfäliche Wilhems-Universität Münster on the 21st and 22nd of November 2002 (Louvain) 73-92

Driessen, J. (2009) 'Excavations on the Kephali at Sissi. Introduction', in Driessen, J., Schoep, I., Carpentier, F., Crevecoeur, I., Devolder, M., Gaignerot-Driessen, F., Hacigüzeller, P., 
Jusseret, S., Langhor, C., Letesson, Q. and Schmitt, A. (eds), Excavations at Sissi. Preliminary Report on the 2007-2008 Campaigns (Louvain) 19-44

Driessen, J. (2012a) 'Excavation at Sissi, (2011) Introduction', in Driessen, J., Schoep, I., Anastasiadou, M., Carpentier, F., Crevecoeur, I., Déderix, S., Devolder, M., GaignerotDriessen, F., Jusseret, S., Langhor, C., Letesson, Q., Liard, F., Schmitt, A., Tsoraki, C. and Veropoulidou, R. (eds), Excavations at Sissi III. Preliminary Report on the 2011 Campaign (Louvain-la-Neuve) 17-26

Driessen, J. (2012b) 'A Matrilocal House Society in Pre- and Protopalatial Crete?', In Schoep, I., Tomkins, P. and Driessen, J. (eds), Back to the Beginning: Reassessing Social and Political Complexity on Crete during the Early and Middle Bronze Age (Oxford) 358-83

Driessen, J. (2016) 'For an Archaeology of Minoan Society. Identifying the Principles of Social Structure', in Cappel, S., Günkel-Maschek, U. and Panagiotopoulos, D. (eds), Minoan Archaeology. Perspectives for the 21st century (Louvain-la-Neuve) 149-66

Driessen, J. (2018) 'Beyond the collective ... The Minoan Palace in action', in Papadatos, Y. and Relaki, M. (eds), From the Foundations to the Legacy of Minoan Society. Studies in honour of Professor Keith Branigan (Oxford) 291-313

Driessen, J., Schoep, I., Carpentier, F., Crevecoeur, I., Devolder, M., Gaignerot-Driessen, F., Hacigüzeller, P., Jusseret, S., Langhor, C., Letesson, Q. and Schmitt, A. (2009) Excavations at Sissi. Preliminary Report on the 2007-2008 Campaigns (Louvain)

Evely, D. (2010) 'Crete', AR 56, 169-200

Ferrara, S. and Jasink, A.M. (2017) 'To have and to hold: hieroglyphic seals as personal marker and objects of display', in Jasink, A.M., Weingarten, J. and Ferrara, S. (eds), Nonscribal Communication Media in the Bronze Age Aegean and Surrounding Areas. The semantics of a-literate and proto-literate media (seals, potmarks, masons' marks, sealimpressed pottery, ideograms and logograms, and related systems) (Florence) 41-54

Ferrence, S.C., Muhly, J.D. and Betancourt, P.P. (2012) 'Affluence in eastern Crete: metal objects from the cemetery of Petras', in Tsipopoulou, M. (ed.), Petras, Siteia - 25 years of excavations and studies. Acts of a two-day conference held at the Danish Institute at Athens, 9-10 October 2010 (Athens) 133-43

Flouda, G. (2013) 'Reassessing the Apesokari Tholos A funerary record: preliminary thoughts', Rivista di Archeologia XXXV, 111-21

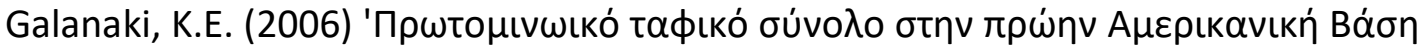

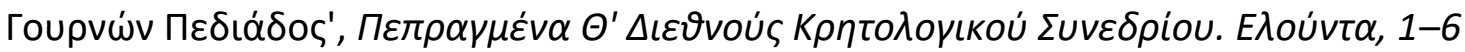

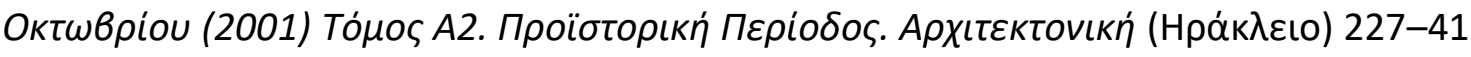

Galanaki, K.E., Bassiakos, Y. and Perdikatsis, V. (2011) 'Silver and Bronze Artifacts from the EM I Necropolis at Gournes, Pediada', in Betancourt, P.P. and Ferrence, S.C. (eds), Metallurgy: understanding how, learning why. Studies in Honor of James D. Muhly (Philadelphia) 79-90 
Galaty, M.L., Parkinson, W.A., Cherry, J.F., Cline, E.H., Kardulias, P.N., Schon, R., Sherratt, S., Thomas, H. and Wengrow, D. (2010) 'Interaction amidst Diversity: and Introduction to the Eastern Mediterranean Bronze Age', in Parkinson, W.A. and Galaty, M.L. (eds), Archaic State Interaction. The Eastern Mediterranean in the Bronze Age (Santa Fe) 29-52

Galli, E. (2014) 'Where the past lies. The Prepalatial Tholos Tomb at Krasi and its stratigraphic sequence', CretChron 34, 231-48

Girella, L. (2012) 'The Kamilari Project publication', Rivista di Archeologia XXXV, 123-36

Girella, L. (2013) 'Exhuming an excavation: preliminary notes on the use of the Kamilari tholos tomb in MM III', in Macdonald, C. and Knappett, C. (eds), Intermezzo: Intermediacy and Regeneration in Middle Minoan III Palatial Crete (London) 149-59

Girella, L. (2018) 'Variables and diachronic diversities in the funerary remains of the Kamilari tholos tombs', in Papadatos, Y. and Relaki, M. (eds), From the Foundations to the Legacy of Minoan Society. Studies in honour of Professor Keith Branigan (Oxford) 115-40

Girella, L. and Todaro, S. (2016) 'Secondary Burials and the Construction of Group Identities in Crete between the Second Half of the 4th and 2nd Millennia BC', in Mina, M., Triantaphyllou, S. and Papadatos, Y. (eds), An Archaeology of Prehistoric Bodies and Embodied Identities in the Eastern Mediterranean (Oxford) 171-9

Giumlia-Mair, A., Betancourt, P.P., Ferrence, S.C. and Muhly, J.D. (2017) 'Special silver alloys from the Pre- and Proto-palatial cemetery of Petras, Crete', in Tsipopoulou, M. (ed), Petras, Siteia. The Pre-and Proto-palatial cemetery in context. Acts of a two-day conference held at the Danish Institute at Athens, 14-15 February 2015 (Aarhus) 203-14

Haggis, D.C. (2005) Kavousi I. The Archaeological Survey of the Kavousi Region (Philadelphia) Hamilakis, Y. (2002) 'Too Many Chiefs?: Factional competition in Neopalatial Crete', in Driessen, J., Schoep, I. and Laffineur, R. (eds), Monuments of Minos. Rethinking the Minoan Palaces. Proceedings of the International Workshop "Crete of the Hundred Palaces?" held at the Université Catholique de Louvain, Louvain-la-Neuve, 14-15 December 2001, Aegaeum 23 (Liège) 179-99

Hamilakis, Y. (2014) 'Sensuous Memory, Materiality and History: Rethinking the 'Rise of the Palaces' on Bronze Age Crete', in Knapp, A.B. and Van Dommelen, P. (eds), The Cambridge Prehistory of the Bronze and Iron Age Mediterranean (Cambridge) 320-36

Hamilakis, Y. (2018) 'The "emergence of the individual" revisited: Memory and transcorporeality in the mortuary landscapes of Bronze Age Crete', in Papadatos, Y. and Relaki, M. (eds), From the Foundations to the Legacy of Minoan Society. Studies in honour of Professor Keith Branigan (Oxford) 313-31

Hayden, B.J. (2003) Reports on the Vrokastro Area, Eastern Crete Volume 1: Catalogue of Pottery from the Bronze and Early Iron Age Settlement of Vrokastro in the Collections of the University of Pennsylvania Museum of Archaeology and Anthropology and the Archaeological Museum, Herakleion, Crete (Philadelphia) 
Hayden, B.J. (2004) Reports on the Vrokastro Area, Eastern Crete Volume 2: The Settlement History of the Vrokastro Area and Related Studies (Philadelphia)

Hayden, B.J. (2005) Reports on the Vrokastro Area, Eastern Crete Volume 3: The Vrokastro Regional Survey Project: Sites and Pottery (Philadelphia)

Hayden, B.J., Bassiakos, Y., Kalpaxis, T., Sarris, A. and Tsipopoulou, M. (2007) 'A New Exploration of Priniatikos Pyrgos: Primary Harbor Settlement and Emporium of the Vrokastro Survey Region', in Betancourt, P.P., Nelson, M.C. and Williams, H. (eds), Krinoi kai Limenes. Studies in Honor of Joseph and Maria Shaw (Philadelphia) 93-100

Hickman, J. (2011) 'The Dog Diadem from Mochlos', in Betancourt, P.P. and Ferrence, S.C. (eds), Metallurgy: understanding how, learning why. Studies in Honor of James D. Muhly (Philadelphia) 91-104

Hickman, J. (2012) 'Gold and Silver Jewelry Production in Prepalatial Crete', in Nosch, M.-L. (ed.), Kosmos. Jewellery, Adornment and Textiles in the Aegean Bronze Age, Aegaeum 33 (Leuven) 523-30

Höflmayer, F. (2017) 'A Radiocarbon Chronology for the Middle Bronze Age Southern Levant', Journal of Ancient Egyptian Interconnections 13, 20-33

Höflmayer, F. (2018) 'An Early Date for Khyan and its Implications for Eastern Mediterranean Chronologies', in Forstner-Müller, I. and Moeller, N. (eds), In the Hyksos ruler Khyan and the Early Second Intermediate Period in Egypt: Problems and Priorities of Current Research. Proceedings of the Workshop of the Austrian Archaeological Institute and the Oriental Institute of the University of Chicago, Vienna, July 4-5, 2014 (Vienna) 143-71

Hood, M.S.F. and Cadogan, G. (2011) Knossos excavations 1957-61: Early Minoan (London) Isaakidou, V. (2017a) 'Feeding the dead, toasting the living? The view from funeral remains', in Tsipopoulou, M. (ed), Petras, Siteia. The Pre-and Proto-palatial cemetery in context. Acts of a two-day conference held at the Danish Institute at Athens, 14-15 February 2015 (Aarhus) 237-44

Isaakidou, V. (2017b) 'Meaningful Materials? Bone Artefacts and Symbolism in the Early Bronze Age Aegean', Oxford Journal of Archaeology 36, 43-59

Isaakidou, V., Livarda, A., Tsoraki, C. and Veropoulidou, R. (2011) 'Bio-archaeological Assemblages and Ground Stone Artefacts', in Driessen, J. (ed.) Excavations at Sissi, II. Preliminary Report on the 2009-2010 Campaigns (Louvain) 211-18

Karacic, S. (2015) 'All aboard: the longboat and a heterarchical interpretation of the Mochlos cemetery', in Cappel, S., Günkel-Maschek, U. and Panagiotopoulos, D. (eds), Minoan Archaeology. Perspectives for the 21st Century (Louvain-La-Neuve) 167-180

Karantzali, E. (2008) 'The Transition of EBI to EBII at Cyclades and Crete: Historical and Cultural Repercussions for Aegean Communities ', in Brodie, N., Doole, J., Gavalas, G. and Renfrew, C. (eds), Horizon/'Opi $\zeta \omega v$. A colloquium on the prehistory of the Cyclades (Cambridge) 241-60 
Krzyszkowska, O. (2012) 'Seals from the Petras cemetery: a preliminary overview', in Tsipopoulou, M. (ed.), Petras, Siteia - 25 years of excavations and studies. Acts of a two-day conference held at the Danish Institute at Athens, 9-10 October 2010 (Athens) 145-60

Krzyszkowska, O. (2017) 'Further seals from the cemetery at Petras', in Tsipopoulou, M. (ed.), Petras, Siteia. The Pre- and Proto-palatial cemetery in context. Acts of a two-day conference held at the Danish Institute at Athens, 14-15 February 2015 (Aarhus) 143-57

Lazaridis, I., Mittnik, A., Patterson, N., Mallick, S., Rohland, N., Pfrengle, S., Furtwängler, A., Peltzer, A., Posth, C., Vasilakis, A., McGeorge, P.J.P., Konsolaki-Yannopoulou, E., Korres, G., Martlew, H., Michalodimitrakis, M., Özsait, M., Özsait, N., Papathanasiou, A., Richards, M., Roodenberg, S.A., Tzedakis, Y., Arnott, R., Fernandes, D.M., Hughey, J.R., Lotakis, D.M., Navas, P.A., Maniatis, Y., Stamatoyannopoulos, J.A., Stewardson, K., Stockhammer, P., Pinhasi, R., Reich, D., Krause, J. and Stamatoyannopoulos, G. (2017) 'Genetic origins of the Minoans and Mycenaeans', Nature 548, 214-8

Legarra Herrero, B. (2009) 'The Minoan fallacy: cultural diversity and mortuary behaviour on Crete at the beginning of the Bronze Age', Oxford Journal of Archaeology 29, 29-57

Legarra Herrero, B. (2011) 'New kid on the block: the nature of the first systemic contacts between Crete and the eastern Mediterranean around 2000 BC', in Wilkinson, T., Sherratt, S. and Bennet, J. (eds), Interweaving worlds: systemic interactions in Eurasia, 7th to 1st millennia BC. Papers from a conference in memory of Professor Andew Sherratt. What Would a Bronze Age World System Look Like? World systems approaches to Europe and western Asia 4th to 1st millennia BC (Oxford) 266-81

Legarra Herrero, B. (2012) 'The Construction, Deconstruction and Non-construction of Hierarchies in the Funerary Record of Prepalatial Crete', in Schoep, I., Tomkins, P. and Driessen, J. (eds), Back to the Beginning: Reassessing Social and Political Complexity on Crete during the Early and Middle Bronze Age (Oxford) 325-57

Legarra Herrero, B. (2014a) Mortuary behaviour and social trajectories in Pre-and Protopalatial Crete (Philadelphia)

Legarra Herrero, B. (2014b) 'The role of gold in South Aegean exchange networks (31001800 BC)', in Meller, H., Risch, R. and Pernicka, E. (eds), Metalle der Macht - Frühes Gold und Silber / Metals of power - Early gold and silver. 6. Mitteldeutscher Archäologentag: vom 17. Bis 19. Oktober 2013 in Halle (Saale) (Halle (Saale)), 467-82

Legarra Herrero, B. (2016a) 'Bodies in a Pickle: burial jars, individualism and group identities in Middle Minoan Crete', in Mina, M., Triantaphyllou, S. and Papadatos, Y. (eds), An Archaeology of Prehistoric Bodies and Embodied Identities in the Eastern Mediterranean (Oxford) 180-88

Legarra Herrero, B. (2016b) 'An elite-infested sea: Interaction and change in Mediterranean paradigms', in Molloy, B. (ed.), 'Of Odysseys and Oddities': Scales and modes of interaction between prehistoric Aegean societies and their neighbours (Oxford) 25-52 
Legarra Herrero, B. (2016c) 'Primary State Formation Processes on Bronze Age Crete: A Social Approach to Change in Early Complex Societies', Cambridge Archaeological Journal 26, 349-67

Legarra Herrero, B. (2018a) '101 ways of creating collective burials. The exceptional Cretan tombs in the context of the 3rd Millennium BC Mediterranean', in Schmitt, A., Déderix, S.A. and Crevecoeur, I. (eds), Gathered in Death. Archaeological and Ethnological Perspectives on Collective Burial and Social Organisation (Louvain) 141-57

Legarra Herrero, B. (2018b) 'Gold, conspicuous consumption and prestige - a relationship in need of review. The case of Early and Middle Bronze Age Crete', in Armada X.-L., MurilloBarroso, M. and Charlton, M. (eds), Metals, Minds and Mobility: Integrating Scientific Data with Archaeological Theory (Oxford) 107-19

Legarra Herrero, B. (2019) Knossos from the Neolithic to the end of the Prepalatial period. Proceedings of the 12th International Congress of Cretan Studies. Herakleion 21-25.9.2016 [Online] Available: https://12iccs.proceedings.gr/en/proceedings/category/39/35/799

Livarda, A. and Kotzamani, G. (2014) 'The Archaeobotany of Neolithic and Bronze Age Crete: Synthesis and Prospects', BSA 108, 1-29

Manning, S. (2008) 'Formation of the Palaces', in Shelmerdine, C.W. (ed.), The Cambridge Companion to the Aegean Bronze Age (Cambridge) 105-20

Manning, S. (2017) 'Comments on Climate, Intra-regional Variations, Chronology, the 2200 B.C. Horizon of Change in the East Mediterranean Region, and Socio-political Change on Crete', in Höflmayer, F. (ed.), The Late Third Millennium in the Ancient Near East. Chronology, C14, and climate change (Chicago) 451-92

Manning, S. (2018) 'The Development of Complex Society on Crete: The Balance between Wider Context and Local Agency', in Knodell, A.R. and Leppard, T.P. (eds), Regional approaches to society and complexity. Studies in honor of John F. Cherry (Sheffield) 29-58

Margaritis, E. (2017) 'The plant remains of the house tombs at Petras: Acts of destruction, transformation and preservation', in Tsipopoulou, M. (ed.) Petras, Siteia. The Pre- and Protopalatial cemetery in context. Acts of a two-day conference held at the Danish Institute at Athens, 14-15 February 2015 (Aarhus) 225-35

Militello, P. (2017) 'Management, power and non-literate communication in Prepalatial and Palatial Mesara', in Jasink, A.M., Weingarten, J. and Ferrara, S. (eds), Non-scribal Communication Media in the Bronze Age Aegean and Surrounding Areas. The semantics of a-literate and proto-literate media (seals, potmarks, masons' marks, seal-impressed pottery, ideograms and logograms, and related systems) (Florence) 55-72

Mina, M. (2016) 'Social Complexity and Gender Inequality in Prepalatial Crete. An argument of Reason or a Reason for Argument?', in Cappel, S., Günkel-Maschek, U. and Panagiotopoulos, D. (eds), Minoan Archaeology. Perspectives for the $21^{\text {st }}$ century (Louvainla-Neuve) 181-98 
Molloy, B., Day, J., Bridgford, S., Isaakidou, V., Nodarou, E., Kotzamani, G., Milic, M., Carter, T., Westlake, Klontza-Jaklova, V., Larsson, E. and Hayden, B.J. (2014) 'Life and Death of a Bronze Age House: Excavation of Early Minoan I Levels at Priniatikos Pyrgos', AJA 118, 30758

Momigliano, N. (2007) 'Late Prepalatial', in Momigliano, N. (ed.), Knossos Pottery Handbook: Neolithic and Bronze Age (Minoan) (London) 79-103

Morero, E. and Prévalet, R. (2015) 'Technological Transfer of Luxury Craftsmanship between Crete and the Orient during the Bronze Age', in Mynářová, J., Onderka, P. and Pavúk, P. (eds), There and Back Again - The Crossroads II. Proceedings of an International COnference held in Prague, September 15-18, 2014 (Prague) 59-84

Muhly, J.D. (2008) 'Ayia Photia and the Cycladic Element in Early Minoan Metallurgy', in Tzachili, I. (ed.), Aegean Metallurgy in the Bronze Age. Proceedings of an International Symposium held at the University of Crete, Rethymnon, Greece, on November 19-21, 2004 (Athens) 69-74

Paliou, E. and Bevan, A. (2016) 'Evolving settlement patterns, spatial interaction and the socio-political organisation of late Prepalatial south-central Crete', AJA 42, 184-97

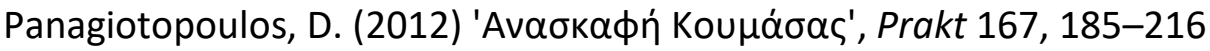

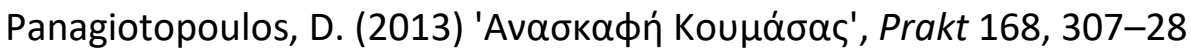

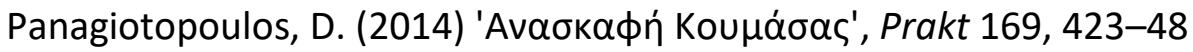

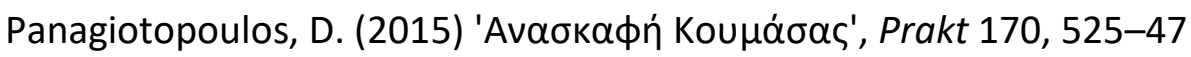

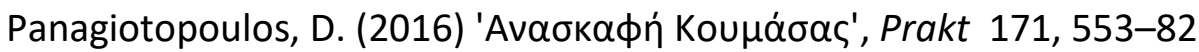

Papadatos, Y. (2005) Tholos Tomb Gamma: A Prepalatial Tholos Tomb at Phourni, Archanes (Philadelphia)

Papadatos, Y. (2007) 'The Beginning of Metallurgy in Crete: New Evidence from the FN-EM I Settlement at Kephala Petras, Siteia', in Day, P.M. and Doonan, R.C.P. (eds), Metallurgy in the Early Bronze Age Aegean (Oxford) 154-67

Papadatos, Y. (2008) 'The Neolithic-Early Bronze Age Transition in Crete: New Evidence from the Settlement at Petras Kephala, Siteia', in Isaakidou, V. and Tomkins, P.D. (eds), Escaping the Labyrinth. The Cretan Neolithic in Context (Oxford) 258-73

Papadatos, Y. (2012a) 'Back to the beginnings: the earliest habitation at Petras on the basis of the evidence from the FN-EM I settlement on Kephala', in Tsipopoulou, M. (ed.), Petras, Siteia - 25 years of excavations and studies. Acts of a two-day conference held at the Danish Institute at Athens, 9-10 October 2010 (Athens) 69-79

Papadatos, Y. (2012b) 'An Early Minoan boat model from Kephala Petras, Siteia', in Matzourani, E. and Betancourt, P.P. (eds), Philistor. Studies in Honor of Costis Davaras (Philadelphia) 155-60 


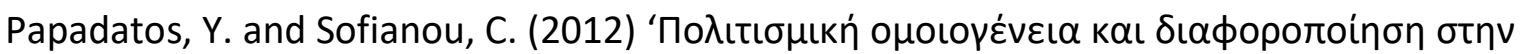

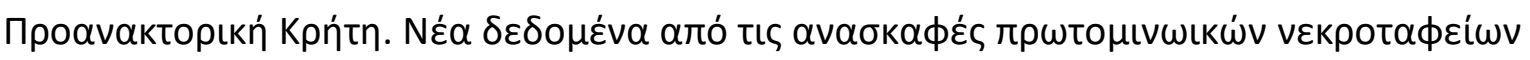

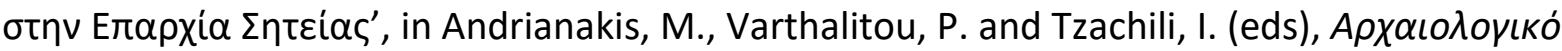

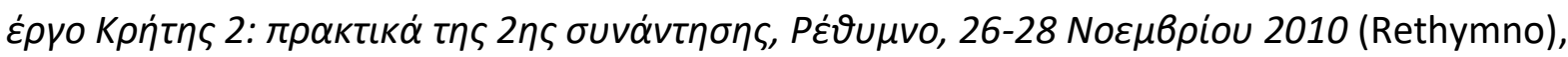
48-59

Papadatos, Y. and Sofianou, C. (2015) Livari Skiadi: A Minoan Cemetery in Lefki, Southeast Crete (Philadelphia)

Papadatos, Y. and Tomkins, P. (2013) 'Trading, the longboat, and cultural interaction in the Aegean during the late fourth millennium BCE: the view from Kephala Petras, east Crete', AJA 117, 353-81

Parkinson, W.A. and Galaty, M.L. (2007) 'Secondary States in Perspective: An Integrated Approach to State Formation in the Prehistoric Aegean', American Anthropologist 109, 11329

Pavlacky, M. (2019) 'Where is the gap? Of the EM III-MM IA period in East Crete', Proceedings of the 12th International Congress of Cretan Studies. Herakleion 21-25.9.(2016) (Herakleion) 1-13 [Online] Available: https://12iccs.proceedings.gr/en/proceedings/category/38/32/602

Phillips, J. (2006) 'Why?... And Why Not? Minoan Reception and Perceptions of Egyptian Influence', in Czerny, E., Hein, I., Hunger, H., Melman, D. and Schwab, A. (eds), Timelines: Studies in Honour of Manfred Bietak (Leuven) 293-300

Phillips, J. (2008) Aegyptiaca on the island of Crete in their chronological context: a critical review. Vol. I (Vienna)

Platon, L. (2017) 'Pezoules Kephala, Zakros I. Form of the tombs and burial habits', in Tsipopoulou, M. (ed.), Petras, Siteia. The Pre-and Proto-palatial cemetery in context. Acts of a two-day conference held at the Danish Institute at Athens, 14-15 February 2015 (Aarhus), 340-54

Platon, L. and Tsiboukaki, M. (2017) 'Pezoules Kephala, Zakros II. The chronological and evaluative position of the finds in the framework of the life of the neighbouring settlement', in Tsipopoulou, M. (ed.), Petras, Siteia. The Pre-and Proto-palatial cemetery in context. Acts of a two-day conference held at the Danish Institute at Athens, 14-15 February 2015 (Aarhus) 355-68

Relaki, M. (2004) 'Constructing a Region: The Contested Landscapes of Prepalatial Mesara', in Barrett, J.C. and Halstead, P. (eds), The Emergence of Civilisation Revisited (Oxford) 17088

Relaki, M. (2010) 'Rethinking administration and seal use in third millennium Crete', Creta Antica 10, 353-72

Relaki, M. (2012) 'The Social Arenas of Tradition. Investigation Collective and Individual Social Strategies in the Prepalatial and Protopalatial Mesara', in Schoep, I., Tomkins, P. and 
Driessen, J. (eds), Back to the Beginning: Reassessing Social and Political Complexity on Crete during the Early and Middle Bronze Age (Oxford) 290-324

Relaki, M. and Tsoraki, C. (2017) 'Variability and differentiation: a first look at the stone vase assemblage in the Petras cemetery', in Tsipopoulou, M. (ed.), Petras, Siteia. The Pre-and Proto-palatial cemetery in context. Acts of a two-day conference held at the Danish Institute at Athens, 14-15 February 2015 (Aarhus) 159-78

Renfrew, C. (1972) The Emergence of Civilisation: The Cyclades and the Aegean in the Third Millennium BC (London)

Renfrew, C. (2004) 'Rethinking The Emergence', in Barrett, J.C. and Halstead, P. (eds), The Emergence of Civilisation Revisited (Oxford) 257-74

Sbonias, K. (2010) 'Diversity and Transformation. Looking for Meanings in the Prepalatial Seal Consumption and Use', in Müller, W. (ed.), Die Bedeutung der minoischen und mykenischen Glyptik. VI. Internationales Siegel-Symposium aus Anlass des 50 jährigen Bestehens des CMS. Marburg, 9. - 12. Oktober 2008 (Mainz am Rhein) 349-62

Sbonias, K. (2012) 'Regional Elite-Groups and the Production and Consumption of Seals in the Prepalatial period. A Case-Study of the Asterousia Region', in Schoep, I., Tomkins, P. and Driessen, J. (eds), Back to the Beginning: Reassessing Social and Political Complexity on Crete during the Early and Middle Bronze Age (Oxford) 236-72

Schoep, I. (2006) 'Looking Beyond the First Palaces: Elites and the Agency of Power in EM IIIMM II Crete', AJA 110, 37-64

Schoep, I. (2009) 'The excavation of the cemetery (zone 1)', in Driessen, J., Schoep, I., Carpentier, F., Crevecoeur, I., Devolder, M., Gaignerot-Driessen, F., Hacigüzeller, P., Jusseret, S., Langhor, C., Letesson, Q. and Schmitt, A. (eds), Excavations at Sissi. Preliminary Report on the 2007-2008 Campaigns (Louvain) 45-56

Schoep, I. (2012) 'Bridging the divide between the 'Prepalatial' and the 'Protopalatial' periods?', in Schoep, I., Tomkins, P. and Driessen, J. (eds), Back to the Beginning:

Reassessing Social and Political Complexity on Crete during the Early and Middle Bronze Age (Oxford) 403-28

Schoep, I. (2018) 'The house tomb in context: Assessing mortuary behaviour', in Papadatos, Y. and Relaki, M. (eds), From the Foundations to the Legacy of Minoan Society. Studies in honour of Professor Keith Branigan (Oxford) 167-89

Schoep, I., Crevecoeur, I., Schmitt, A. and Tomkins, P. (2017) 'Funerary practices at Sissi: The treatment of the body in the house tombs', in Tsipopoulou, M. (ed.), Petras, Siteia. The Preand Proto-palatial cemetery in context. Acts of a two-day conference held at the Danish Institute at Athens, 14-15 February 2015 (Aarhus) 369-84

Schoep, I. and Knappett, C. (2004) 'Dual Emergence: Evolving Heterarchy, Exploding Hierarchy', in Barrett, J.C. and Halstead, P. (eds), The Emergence of Civilisation Revisited (Oxford) 21-37 
Schoep, I., Schmitt, A. and Crevecoeur, I. (2011) 'The Cemetery at Sissi. Report of the 2009 and 2010 Campaigns', in Driessen, J., Schoep, I., Carpentier, F., Crevecoeur, I., Devolder, M., Gaignerot-Driessen, F., Hacigüzeller, P., Isaakidou, V., Jusseret, S., Langhor, C., Letesson, Q. and Schmitt, A. (eds), Excavations at Sissi, II. Preliminary Report on the 2009-2010 Campaigns (Louvain) 41-68

Schoep, I., Schmitt, A., Crevecoeur, I. and Déderix, S. (2013) 'The Cemetery at Sissi. Report of the 2011 Campaign', in Driessen, J., Schoep, I., Anastasiadou, M., Carpentier, F., Crevecoeur, I., Déderix, S., Devolder, M., Gaignerot-Driessen, F., Jusseret, S., Langhor, C., Letesson, Q., Liard, F., Schmitt, A., Tsoraki, C. and Veropoulidou, R. (eds), Excavations at Sissi, III. Preliminary Report on the 2011 Campaign (Louvain) 27-51

Schoep, I. and Tomkins, P. (2012) 'Back to the Beginning For the Early and Middle Bronze Age on Crete', in Schoep, I., Tomkins, P. and Driessen, J. (eds), Back to the Beginning: Reassessing Social and Political Complexity on Crete during the Early and Middle Bronze Age (Oxford) 1-31

Shaw, J.W. (2016) 'Central ceiling and roof supports in Early Minoan II architecture', BSA $111,51-69$

Shaw, J.W. (2017) 'Access to upper floors and an early light well at EM II Vasiliki', BSA 112, 33-45

Soar, K. (2014) 'Sects and the city: factional ideologies in representations of performance from Bronze Age Crete', World Archaeology 46, 224-41

Soar, K. (2016) 'Cultural Performances at the Beginning of the Bronze Age. Early Minoan I and II Cemeteries as Stages for Performance', in Cappel, S., Günkel-Maschek, U. and Panagiotopoulos, D. (eds), Minoan Archaeology. Perspectives for the 21st century (Louvainla-Neuve) 283-97

Soles, J.S. (2012) 'Mochlos boats', in Matzourani, E. and Betancourt, P.P. (eds), Philistor. Studies in Honor of Costis Davaras (Philadelphia) 187-200

Stampolidis, N. and Sotirakopoulou, P. (eds) (2017) Cycladica in Crete. Cycladic and Cycladicizing figurines within their archaeological context. Proceedings of the International Symposium, Museum of Cycladic Art. Athens 1-2 October 2015 (Athens)

Todaro, S. (2004) 'Haghia Triada nel periodo Antico Minoico', Creta Antica 4, 73-96

Todaro, S. (2005) 'EM I - MM IA ceramic groups at Phaistos: towards the definition of a Prepalatial ceramic sequence in South Central Crete', Creta Antica 6, 11-46

Todaro, S. (2009) 'The latest Prepalatial period and the foundation of the first palace at Phaistos: a stratigraphic and chronological re-assessment', Creta Antica 10, 105-45

Todaro, S. (2010) 'Pottery production in the Prepalatial Mesara: The Artisan's quarter to the west of the Palace at Phaistos', Creta Antica 10, 333-52 
Todaro, S. (2012) 'Craft Production and Social Practices at Prepalatial Phaistos: the Background to the First 'Palace", in Schoep, I., Tomkins, P. and Driessen, J. (eds), Back to the Beginning: Reassessing Social and Political Complexity on Crete during the Early and Middle Bronze Age (Oxford) 195-235

Tomkins, P. (2012) 'Behind the Horizon: Reconsidering the Genesis and Function of the 'First Palace' at Knossos (Final Neolithic IV-Middle Minoan IB)', in Schoep, I., Tomkins, P. and Driessen, J. (eds), Back to the Beginning: Reassessing Social and Political Complexity on Crete during the Early and Middle Bronze Age (Oxford) 32-80

Tomkins, P. (2018) 'Inspecting the foundations: The Early Minoan Project in review', in Papadatos, Y. and Relaki, M. (eds), From the Foundations to the Legacy of Minoan Society. Studies in honour of Professor Keith Branigan (Oxford) 36-67

Tomkins, P.D. (2004) 'Filling in the 'Neolithic Background': Social Life and Social Transformation in the Aegean Before the Bronze Age', in Barrett, J.C. and Halstead, P. (eds), The Emergence of Civilisation Revisited (Oxford) 38-63

Triantaphyllou, S. (2005) 'The Human Remains', in Papadatos, Y. (ed.) Tholos Tomb Gamma. A Prepalatial Tholos Tomb at Phourni, Archanes (Philadelphia) 66-76

Triantaphyllou, S. (2009) 'EM / MM Human skeletal remains from east Crete: the Kephala Petras Rock Shelter, Siteia and the Livari Tholos Tomb, Skiadi', Kentro 12, 19-23

Triantaphyllou, S. (2010) 'Analysis of the human bones', in Vasilakis, A. and Branigan, K. (eds), Moni Odigitria. A Prepalatial cemetery and its Environs in the Asterousia, Southern Crete (Philadelphia) 229-48

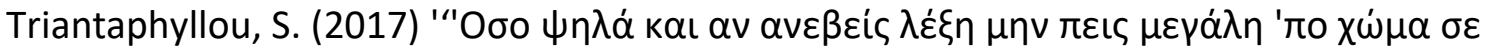

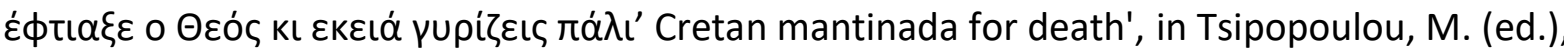
Petras, Siteia. The Pre-and Proto-palatial cemetery in context. Acts of a two-day conference held at the Danish Institute at Athens, 14-15 February 2015 (Aarhus) 271-90

Triantaphyllou, S. (2018) 'Mortuary variability, social differentiation and ranking in Prepalatial Crete: The evidence from the cemetery of Phourni, Archanes', in Papadatos, Y. and Relaki, M. (eds), From the Foundations to the Legacy of Minoan Society. Studies in honour of Professor Keith Branigan (Oxford) 141-66

Triantaphyllou, S., Kiorpe, S. and Tsipopoulou, M. (2017) 'House Tomb 5: A preliminary analysis of the human skeletal remains', in Tsipopoulou, M. (ed.), Petras, Siteia. The Pre- and Proto-palatial cemetery in context. Acts of a two-day conference held at the Danish Institute at Athens, 14-15 February 2015 (Aarhus) 291-300

Triantaphyllou, S., Nikita, E. and Kador, T. (2015) 'Exploring mobility patterns and biological affinities in the Southern Aegean: first insights from Early Bronze Age Eastern Crete', BSA $110,3-25$ 
Tselios, T. (2008) 'Pre-palatial Copper Metalworking in the Mesara Plain, Crete', in Tzachili, I. (ed.), Aegean Metallurgy in the Bronze Age. Proceedings of an International Symposium held at the University of Crete, Rethymnon, Greece, on November 19-21, 2004 (Athens) 123-32

Tsipopoulou, M. (1999) 'Before, During, After: The Architectural Phases of the Palatial Building at Petras, Siteia', in Betancourt, P.P., Karageorghis, R., Laffineur, R. and Niemeier, W.D. (eds), Meletemata. Studies in Aegean Archaeology Presented to Malcolm H. Wiener as He Enters His 65th Year, Aegaeum 20 (Liège) 847-55

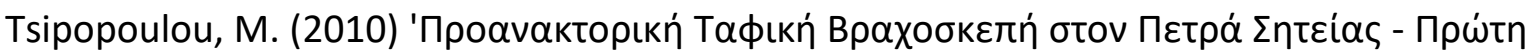

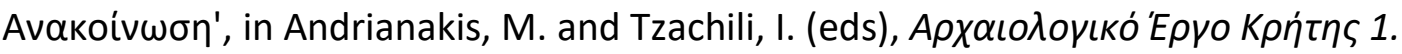

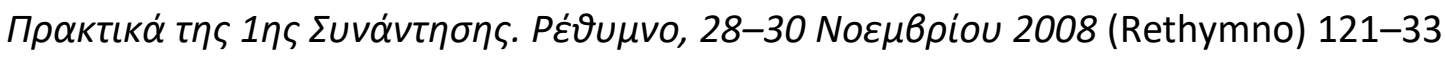

Tsipopoulou, M. (2012a) 'Introduction: 25 years of excavations and studies at Petras', in Tsipopoulou, M. (ed.), Petras, Siteia - 25 years of excavations and studies. Acts of a two-day conference held at the Danish Institute at Athens, 9-10 October 2010 (Athens) 45-68

Tsipopoulou, M. (2012b) 'Kampos Group Pottery from the Cemetery of Petras, Siteia', in Mantzourani, E. and Betancourt, P.P. (eds), Philistor. Studies in Honor of Costis Davaras (Philadelphia) 213-22

Tsipopoulou, M. (2012c) 'The Prepalatial-early Protopalatial cemetery at Petras, Siteia: a diachronic symbol of social coherence', in Tsipopoulou, M. (ed.), Petras, Siteia - 25 years of excavations and studies. Acts of a two-day conference held at the Danish Institute at Athens, 9-10 October 2010 (Athens) 117-31

Tsipopoulou, M. (2017a) 'Ceremonial Area 1: Identity and dating of a special ritual space in the Petras cemetery', in Tsipopoulou, M. (ed.), Petras, Siteia. The Pre- and Proto-palatial cemetery in context. Acts of a two-day conference held at the Danish Institute at Athens, 1415 February 2015 (Aarhus) 111-30

Tsipopoulou, M. (2017b) 'Documenting sociopolitical changes in Pre- and Proto-palatial Petras: The house tomb cemetery', in Tsipopoulou, M. (ed.), Petras, Siteia. The Pre-and Proto-palatial cemetery in context. Acts of a two-day conference held at the Danish Institute at Athens, 14-15 February 2015 (Aarhus) 57-103

Tsoraki, C. (2012) 'Ground stone technologies at the Bronze Age settlement of Sissi', in Driessen, J. (ed.), Excavatinos at Sissi III. Preliminary Report on the 2011 Campaign (Louvain) 201-19

Vander Linden, M. (2016) 'Population history in third-millennium-BC Europe: assessing the contribution of genetics', World Archaeology 48, 714-28

Vasilakis, A. and Branigan, K. (2010) Moni Odigitria. A Prepalatial Cemetery and its Environs in the Asterousia, Southern Crete (Philadelphia)

Vasilakis, A. and Sbonias, K. (2018) 'Comparative issues in archaeological field survey in the Asterousia Mountains', in Papadatos, Y. and Relaki, M. (eds), From the Foundations to the Legacy of Minoan Society. Studies in honour of Professor Keith Branigan (Oxford) 275-90 


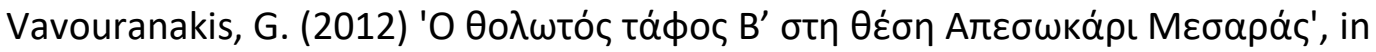

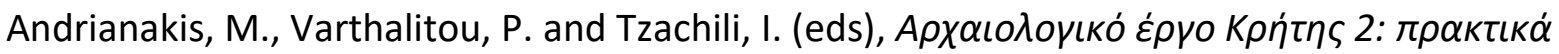

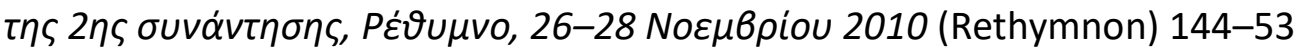

Vavouranakis, G. (2017) 'Funerary ritual and social structure in the Old Palace period: A multifarious liaison', in Tsipopoulou, M. (ed.), Petras, Siteia. The Pre-and Proto-palatial cemetery in context. Acts of a two-day conference held at the Danish Institute at Athens, 1415 February 2015 (Aarhus) 385-98

Vavouranakis, G. and Bourbou, C. (2015) 'Breaking up the Past: Patterns of Fragmentation in Early and Middle Bronze Age Tholos Tomb Contexts in Crete', in Harrell, K. and Driessen, J. (eds), Thravsma. Contextualising the Intentional Destruction of Objects in the Bronze Age Aegean and Cyprus (Louvain) 167-96

Veropoulidou, R. (2012) 'Sissi: The Shell Assemblages', in Driessen, J. (ed.) Excavations at Sissi III. Preliminary Report on the 2011 Campaign (Louvain) 185-200

Warren, P. (2005) 'A model of iconographical transfer. The case of Crete and Egypt', in

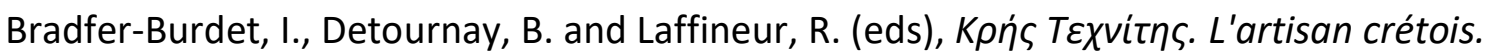
Recueil d'articles en I'honneur de Jean-Claude Poursat, publié à l'occasion des 40 ans de la découverte du Quartier Mu, Aegaeum 26 (Liège) 221-27

Watrous, L.V. (1994) 'Crete from earliest prehistory through the Protopalatial period', AJA $98,698-753$

Watrous, L.V. (2001) 'Addendum: 1994-1999', in Cullen, T. (ed.) Aegean prehistory: a review (Boston) 216-23

Watrous, L.V. (2005) 'Cretan International Relations during the Middle Minoan IA Period and the Chronology of Seager's Finds from the Mochlos Tombs', in Laffineur, R. and Greco, E. (eds), Emporia. Aegeans in the central and eastern Mediterranean. Proceedings of the 10th International Aegean Conference /10e Rencontre égñeenne internationale. Athens, Italian School of Archaeology, 14-18 April (2004), Aegaeum 25 (Liège) 107-16

Watrous, L.V. (2012) An archaeological survey of the Gournia landscape: a regional history of the Mirabello Bay, Crete, in antiquity (Philadelphia)

Watrous, L.V., Buell, D.M., McEnroe, J.C., Younger, J.G., Turner, L.A., Kunkel, B.S., Glowacki, K., Gallimore, S., Smith, A., Pantou, P.A., Chapin, A. and Margaritis, E. (2015) 'Excavations at Gournia, 2010-2012', Hesperia 84, 397-465

Watrous, L.V., Buell, M., Kokinou, E., Soupios, P., Sarris, A., Rethemiotakis, G., Turner, L.A., Gallimore, S., Hammond, M.D. (2017) The Galatas survey: Socio-Economic and Political Development of a Contested Territory in Central Crete during the Neolithic to Ottoman Periods (Philadelphia)

Watrous, L.V., Hadzi-Vallianou, D. and Blitzer, H. (2004) The Plain of Phaistos: Cycles of Social Complexity in the Mesara Region of Crete (Los Angeles) 
Weiberg, E. (2017) 'Contrasting Histories in Early Bronze Age Aegean: Uniformity, Regionalism and the Resilience of Societies in the Northeast Peloponnese and Central Crete', Cambridge Archaeological Journal 27, 479-94

Weiberg, E., Bevan, A., Kouli, K., Katsianis, M., Woodbridge, J., Bonnier, A., Engel, M., Finné, M., Fyfe, R., Maniatis, Y., Palmisano, A., Panajiotidis, S., Roberts, C.N. and Shennan, S. (2019) 'Long-term trends of land use and demography in Greece: A comparative study', The Holocene 29, 742-60

Whitelaw, T.M. (2004a) 'Alternative Pathways to Complexity in the Southern Aegean', in Barrett, J.C. and Halstead, P. (eds), The Emergence of Civilisation Revisited (Oxford) 232-56

Whitelaw, T.M. (2004b) 'Estimating the population of Neopalatial Knossos', in Cadogan, G., Hatzaki, E. and Vasilakis, A. (eds), Knossos: Palace, City, State. Proceedings of the Conference in Herakleion organised by the British School at Athens and the 23rd Ephoreia of Prehistoric and Classical Antiquities of Herakleion, in November 2000, for the Centenary of Sir Arthur Evans' Excavations at Knossos (London) 147-58

Whitelaw, T.M. (2012a) 'Collecting citites: some problems and prospects', in Johnson, P. and Millett, M. (eds), Archaeological survey and the city (Oxford)

Whitelaw, T.M. (2012b) 'The Urbanisation of Prehistoric Crete: Settlements Prespectives on Minoan State Formation', in Schoep, I., Tomkins, P. and Driessen, J. (eds), Back to the Beginning: Reassessing Social and Political Complexity on Crete during the Early and Middle Bronze Age (Oxford) 114-76

Whitelaw, T.M. (2017) 'The development and character of urban communities in Prehistoric Crete in their regional context: a preliminary study', in Letesson, Q. and Knappett, C. (eds), Minoan architecture and urbanism. New perspectives on an Ancient Built Environment (Oxford) 114-80

Whitelaw, T.M. (2018) 'Recognising polities in prehistoric Crete', in Papadatos, Y. and Relaki, M. (eds), From the Foundations to the Legacy of Minoan Society. Studies in honour of Professor Keith Branigan (Oxford) 210-55

Wiener, M.H. (2013) 'Contacts: Crete, Egypt, and the Near East circa 2000 B.C.', in Aruz, J., Graff, S.B. and Rakic, Y. (eds), Cultures in Contact. From Mesopotamia to the Mediterranean in the Second Millennium B.C. (New York) 34-45

Wilson, D.E. (2007) 'Early Prepalatial', in Momigliano, N. (ed.) Knossos Pottery Handbook: Neolithic and Bronze Age (Minoan) (London) 49-77

Wilson, D.E. (2008) 'Early Prepalatial Crete', in Shelmerdine, C.W. (ed.) The Cambridge Companion to the Aegean Bronze Age (Cambridge) 77-104

Wilson, D.E. (2010) 'Knossos 1955-1957: Early Prepalatial Deposits from Platon's Tests in the Palace', BSA 105, 97-155

Wilson, D.E., Day, P.M. and Dimopoulou-Rethemiotaki, N. (2008) 'The Gateway Port of Poros-Katsambas: Trade and Exchange between North-central Crete and the Cyclades in EBI- 
II', in Brodie, N., Doole, J., Gavalas, G. and Renfrew, C. (eds), Horizon/Opi $\zeta \omega v$. A colloquium on the prehistory of the Cyclades (Cambridge) 261-70

Map

Map 1: Early Bronze Age sites mentioned in the article. Add sites that you want to see on the map - sites should appear in geographical order; as per Andrew's comment above - we need an excel table with the sites and their coordinates (referenced in Google Earth) to prepare the map.

Figures

Figure 1: Add captions + Source

Figure 2:

Figure 3:

Figure 4:

Figure 5:

Figure 6:

Figure 7:

Figure 8:

Figure 9:

You can select a few more images (up to 15?) from AGonline, if you like. 